Nicholas, D. J. D. \& Commissiong, K. (1957). J. gen. Microbiol. 17, 699-707

\title{
Effects of Molybdenum, Copper and Iron on Some Enzymes in Neurospora crassa
}

\author{
By D. J. D. NICHOLAS AND K. COMMISSIONG \\ A.R.C. Unit of Plant Nutrition (Micronutrients), Long Ashton \\ Research Station, University of Bristol
}

SUMMARY : Diverse enzyme changes were obtained in Neurospora crassa grown at deficient, optimal and toxic levels of $\mathrm{Mo}, \mathrm{Cu}$ and $\mathrm{Fe}$. These included mutual antagonisms between the metals, single effects of one element or additive ones of more than one element. Cytochrome $c$ oxidase content, enhanced by $\mathrm{Cu}$ treatment, was decreased by increasing Mo; the reverse relationship was obtained with nitrate reductase. Cytochrome $c$ and nitrite reductases, however, were depressed by amounts both of $\mathrm{Cu}$ and Mo which were toxic to growth; the effects were additive. Single effects were as follows: TPNH diaphorase and acid phosphatase were depressed by $\mathrm{Cu}$ and Mo excess respectively; the iron enzymes and the two diaphorases were more active when $\mathrm{Fe}$ was increased from deficiency to sufficiency level. High iron concentrations increased nitrate reductase but depressed the nitrite system. Molybdenum is shown to inhibit acid phosphatase competitively in vitro, presumably by forming a molybdo-phosphate addition compound with the substrate. Cu dispersed this complex and restored the enzyme activity to normal. Vanadate or tungstate had a similar effect to molybdate in depressing the enzyme but $\mathrm{Cu}$ was found to reverse the inhibition.

Thus it appears that antagonisms between metals in nutrition experiments may be related to their effects on certain enzymes as illustrated here for $\mathrm{Cu}$, Mo and $\mathrm{Fe}$ in Neurospora.

Antagonisms between nutrients are well established in plants and animals but little is known how these affect cell metabolism. Healy, Cheng \& McElroy (1955) showed that the effect of Co excess in depressing iron-containing enzymes in Neurospora crassa was partially reversed by increasing $\mathrm{Fe}$ in the culture solution. van Reen (1953) demonstrated that $\mathrm{Zn}$ toxicity in the rat decreased the amount of depressed liver catalase and cytochrome $c$ oxidase and that this effect was remedied by adding copper sulphate to the diet.

This paper amplifies a preliminary report in which it was shown that $\mathrm{Cu}$ and Mo were reciprocally antagonistic towards cytochrome $c$ oxidase and nitrate reductase in Neurospora crassa (Commissiong \& Nicholas, 1957); the effects of iron concentration on some enzymes are also considered.

\section{METHODS}

Culture medium. Neurospora crassa, macroconidial wild type 5297a, was grown in the following medium: sucrose, $20 \mathrm{~g}$; $\mathrm{Na}$ tartrate, $\mathbf{I}$ g.; $\mathrm{KH}_{2} \mathrm{PO}_{4}$, 3 g.; $\mathrm{MgSO}_{4} .7 \mathrm{H}_{2} \mathrm{O}, 0.5 \mathrm{~g}$.; $\mathrm{NaCl}, 0.1 \mathrm{~g}$.; $\mathrm{CaCl}_{2}, 0.1 \mathrm{~g}$. After removing $\mathrm{Fe}, \mathrm{Cu}$ and Mo from the macronutrients (Nicholas, 1952), the following micronutrients were added: biotin, $5 \mu \mathrm{g}$.; $\mathrm{Zn}$ as $\mathrm{ZnSO}_{4} \cdot 7 \mathrm{H}_{2} \mathrm{O}, 200 \mu \mathrm{g}$.; $\mathrm{Mn}$ as $\mathrm{MnCl}_{2} .4 \mathrm{H}_{2} \mathrm{O}, 20 \mu \mathrm{g}$; $\mathrm{Cu}$ as $\mathrm{CuSO}_{4} \cdot 5 \mathrm{H}_{2} \mathrm{O}$ at $0,0.08 \mathrm{mg}$. or $10 \mathrm{mg}$.; $\mathrm{Mo}$ as 
$\mathrm{Na}_{2} \mathrm{MoO}_{4} \cdot 2 \mathrm{H}_{2} \mathrm{O}$ at $0,0.02 \mathrm{mg}$. or $200 \mathrm{mg}$.; $\mathrm{Fe}$ as $\mathrm{FeCl}_{3} .6 \mathrm{H}_{2} \mathrm{O}$ at $0,0.2 \mathrm{mg}$. or $35 \mathrm{mg}$.; distilled water, $1 \mathrm{l}$.; $\mathrm{pH} 4 \cdot 8$. The three concentrations of $\mathrm{Fe}, \mathrm{Cu}$ and $\mathrm{Mo}$ represented deficiency (0), normal (1), and toxicity concentrations (2), based on the dry weight yields of the felts.

Purification of culture media. Fe, Cu and Mo were removed from the macronutrients by the copper co-precipitation and quinoline methods (Nicholas, 1952). The micronutrient elements $\mathrm{Fe}, \mathrm{Cu}, \mathrm{Mn}, \mathrm{Zn}$ and $\mathrm{Mo}$ were used as 'spectroscopically pure' compounds supplied by Johnson and Mathey (Hatton Garden, London, E.C. 1 ). Biotin (25 $\mu \mathrm{g}$.$) dispensed in phosphate$ buffer ( $\mathrm{pH} 7$ ) was supplied in ampoules by the Ashe Laboratories (Leatherhead, Surrey). The culture medium $(200 \mathrm{ml}$.) was dispensed in $1 \mathrm{l}$. Erlenmeyer flasks, and after sterilizing at $10 \mathrm{lb} . / \mathrm{sq} . \mathrm{in}$. for $10 \mathrm{~min}$. and cooling, various amounts of $\mathrm{Fe}, \mathrm{Cu}$ and Mo were added to their respective containers. The media were then inoculated with a spore suspension of Neurospora crassa 5297 a in glass-distilled water and incubated for 4 days at $30^{\circ}$ in the dark. The cultures were shaken periodically to prevent sporulation.

Preparation of cell-free extracts. The mycelial felts from each of the twentyseven treatments, collected separately in sintered Buchner funnels, were washed thoroughly with glass-distilled water and frozen overnight at $-17^{\circ}$. They were then homogenized, in groups of nine, in four times their weight of cold 0.1 M-phosphate buffer ( $\mathrm{pH} \mathrm{7.5)}$ in a mortar and then in a Ten Broeck glass macerator at $0^{\circ}$. The homogenates were centrifuged at $3000 \mathrm{~g}$ for $10 \mathrm{~min}$. at $4^{\circ}$ and the supernatant solutions used for enzyme assays.

Cofactors and other compounds. Diphosphopyridine nucleotide (DPN), triphosphopyridine nucleotide (TPN) (both of $95 \%$ purity) and cytochrome $c$ were obtained from the Sigma Chemical Company, U.S.A. Reduced DPN was prepared enzymically by the alcohol dehydrogenase method of Pullman, Colowick \& Kaplan (1952) and reduced TPN by using the isocitric dehydrogenase enzyme from acetone powder of pig heart. Boiled pig heart extract, centrifuged at $18,000 \mathrm{~g}$ for $20 \mathrm{~min}$. at $4^{\circ}$, was used as a source of flavine adenine dinucleotide (FAD).

Catalase activity was measured at $37^{\circ}$ by the perborate method of Feinstein (1949). The reaction mixture contained $8 \mathrm{ml}$. $1.5 \%(\mathrm{w} / \mathrm{v}) \mathrm{NaBO}_{3} .4 \mathrm{H}_{2} \mathrm{O}$ (pH 6.8); $1.9 \mathrm{ml} .0 .1 \mathrm{M}$-phosphate buffer (pH 6.8);0.1 ml. enzyme extract; this was incubated at $37^{\circ}$ for $5 \mathrm{~min}$. Then $10 \mathrm{ml} .2 \mathrm{~N}-\mathrm{H}_{2} \mathrm{SO}_{4}$ was added and the solution titrated with $0.05 \mathrm{~N}-\mathrm{KMnO}_{4}$. The values are expressed as $\mathrm{m}$-mole perborate degraded $/ 5 \mathrm{~min} . / \mathrm{mg}$. protein.

Peroxidase was determined by the spectrophotometric method of Smith, Robinson \& Stotz (1949). The reaction mixture contained $1.45 \mathrm{ml}$. McIlvaine's buffer $(\mathrm{pH} \mathrm{6.0}) ; 1.0 \mathrm{ml} .10^{-3}$ reduced $\mathrm{M}-2: 6$-dichloroindophenol; $0.5 \mathrm{ml} .0 .1 \mathrm{M}-\mathrm{H}_{2} \mathrm{O}_{2} ; 0.05 \mathrm{ml}$. enzyme extract. The oxidation of the dye was followed at $625 \mathrm{~m} \mu$. at $15 \mathrm{sec}$. intervals. The unit of activity was the change in $\log I_{0} / I$ of $0.001 / \mathrm{min}$. calculated between 15 and $75 \mathrm{sec} . / \mathrm{mg}$. protein.

DPNH and TPNH oxidases ('diaphorase' systems) were measured by following dye reduction at $625 \mathrm{~m} \mu$. The reaction mixture used was: $2.85 \mathrm{ml}$. $0 \cdot 1 \mathrm{M}$-phosphate buffer $(\mathrm{pH} \mathrm{7.5}) ; 0.15 \mathrm{ml} .1 \times 10^{-3} \mathrm{M}-2: 6$-dichloroindophenol; 
$0.1 \mathrm{ml}$. 0.1 M-KCN; $0.05 \mathrm{ml}$. DPNH $\left(10^{-3} \mathrm{M}\right)$ or TPNH (2 $\mu \mathrm{mole} / \mathrm{ml}$. $) ; 0.05 \mathrm{ml}$. enzyme extract.

Cytochrome c oxidase was estimated by the method of Smith \& Stotz (1949). The reaction mixture contained $1.95 \mathrm{ml}$. 0.1 M-phosphate $(\mathrm{pH} \mathrm{6.8);1.0} \mathrm{ml.}$ $10^{-3}$ reduced M-2:6-dichloroindophenol; $0.2 \mathrm{ml}$. $1 \times 10^{-4} \mathrm{M}$-cytochrome $c$; $0.05 \mathrm{ml}$. enzyme extract. The unit of activity was the change in $\log I_{0} / I$ of $0 \cdot 001 / \mathrm{min}$. calculated between 15 and $75 \mathrm{sec} . / \mathrm{mg}$. protein.

DPN-cytochrome c reductase was measured at $551 \mathrm{~m} \mu$. The reaction solution contained 2.65 ml. 0.1 M-phosphate buffer (pH 7.5); $0.03 \mathrm{ml}$. 0.1 M-KCN; $0 \cdot 2 \mathrm{ml} .0 \cdot 1 \mathrm{M}-\mathrm{MgCl}_{2} .6 \mathrm{H}_{2} \mathrm{O} ; 0.1 \mathrm{ml}$. cytochrome $c, 3 \times 10^{-3} \mathrm{M} ; 0 \cdot 1 \mathrm{ml}$. DPNH $\left(10^{-3} \mathrm{M}\right) ; 0 \cdot 1 \mathrm{ml}$. enzyme extract.

Nitrate reductase was measured by the method of Nicholas, Nason \& McElroy (1954). The assay method consisted of adding $0.1 \mathrm{ml}$. enzyme extract to a solution containing $0 \cdot 1 \mathrm{ml} .0 \cdot 1 \mathrm{M}-\mathrm{KNO}_{3} ; 0.1 \mathrm{ml}$. boiled pig heart extract; $0.1 \mathrm{ml}$. $10^{-4} \mathrm{M}-\mathrm{KCN} ; \quad 0.1 \mathrm{ml} . \quad 1 \times 10^{-3} \mathrm{M}-\mathrm{TPNH} ; 0.1 \mathrm{ml}$. $0.1 \mathrm{M}$-phosphate buffer (pH 7.5). The mixture was incubated for $10 \mathrm{~min}$. at $25^{\circ}$. and the reaction stopped by adding $1.0 \mathrm{ml} .0 .001 \%$ (w/v) $N$-(1-naphthyl)-ethylenediamine dihydrochloride reagent followed by $0.5 \mathrm{ml} .1 \%(\mathrm{w} / \mathrm{v})$ sulphanilamide reagent. The volume was made up to $5 \mathrm{ml}$. with glass-distilled water and read on the Spekker absorptiometer, after $10 \mathrm{~min}$., at $540 \mathrm{~m} \mu$. Control tests without TPNH were used to correct for the turbidity of the enzyme preparation. Units of activity are expressed as $\mathrm{m} \mu$ mole $\mathrm{NO}_{3}^{-}$formed in $10 \mathrm{~min} . / \mathrm{mg}$. protein.

Nitrite reductase was determined by the method described by Medina \& Nicholas (1957). The test consisted of adding $0.1 \mathrm{ml}$. enzyme to a solution containing $0.2 \mathrm{ml} .10^{-3} \mathrm{M}-\mathrm{NaNO}_{2} ; 0.1 \mathrm{ml}$. boiled pig heart extract; $0.1 \mathrm{ml}$. DPNH $\left(10^{-3} \mathrm{M}\right)$ and $0.25 \mathrm{ml}$. 0.1 M-pyrophosphate buffer (pH 7.5). After $10 \mathrm{~min}$. incubation at $25^{\circ}, 0 \cdot 1 \mathrm{ml}$. 1.0 M-Ba acetate and $3 \cdot 15 \mathrm{ml}$. cold absolute ethanol were added. The mixture was stirred well, left at $4^{\circ}$ for $30 \mathrm{~min}$. and the precipitate centrifuged down; $0.5 \mathrm{ml}$. of the supernatant fluid was then taken and the colour developed as in the nitrate reductase assay.

Alkaline and acid phosphatases were estimated by the method of Bessey, Lowry \& Brock (1946) in which the breakdown of $p$-nitrophenylphosphate to $p$-nitrophenol formed in $30 \mathrm{~min} . / \mathrm{mg}$. protein was determined at alkaline and acid $\mathrm{pH}$.

Protein was determined by the Folin method as described by Lowry, Rosebrough, Farr \& Randall (1951).

\section{RESULTS}

Enzyme assays were made on the extracts from the mycelial felts of each of the twenty-seven treatment combinations; the results were analysed statistically.

\section{Iron-containing enzymes}

Effect of iron concentration. Catalase, peroxidase, cytochrome $c$ oxidase and its reductase were all affected by an increase in iron concentration as illustrated in Fig. 1. Their means showed in each case a significant increase from the $\mathbf{F e}_{\mathbf{0}}$ 
to the $\mathbf{F e}_{1}$ level. Cytochrome $c$ oxidase was depressed at Fe concentrations that depressed growth.

Effect of copper. Of the four iron-containing enzymes examined, only cytochrome $c$ oxidase and cytochrome $c$ reductase were significantly affected by the copper treatment. From deficiency to the toxicity level of the metal, based on growth measurements, catalase activity decreased steadily.

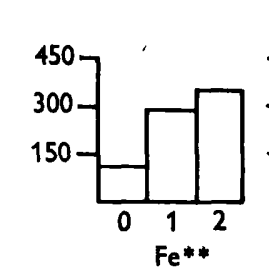

\section{Catalase}
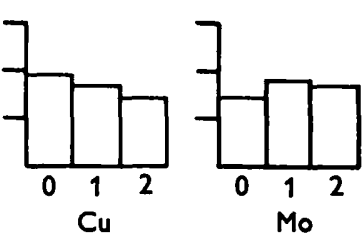

Significant diff. for metal means:

$101.9(5 \%)$

$154.3(1 \%)$

$248.0(0.1 \%)$

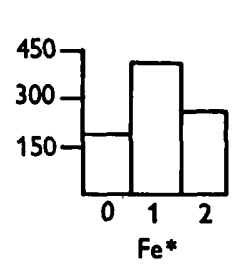

\section{Peroxidase}
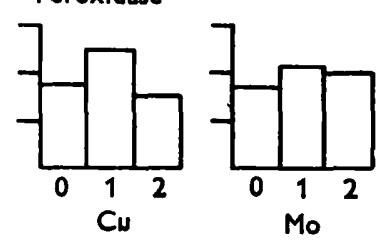

Significant diff.

for metal means :

$155.0(5 \%)$

$234.8(1 \%)$

$377.5(0.1 \%)$

Cytochrome $c$ oxidase
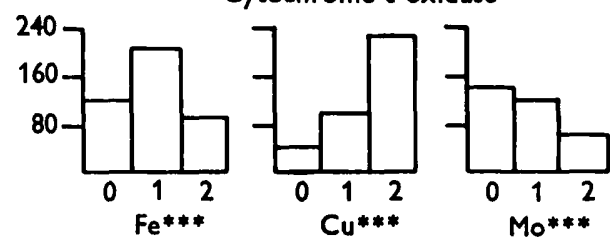

Significant diff.

for metal means :

$27.6(5 \%)$

41.8 (1\%)

$67.2(0.1 \%)$

Cytochrome $c$ reductase
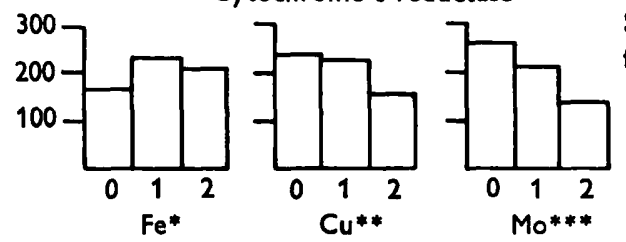

Significant diff.

for metal means:

$37.1(5 \%)$

$56.1(1 \%)$

$90.2(0.1 \%)$

Significant at: * $(5 \%$ level $) i^{* *}(1 \%$ level $) ; * * *(0 \cdot 1 \%$ level $)$.

Fig. 1. Ordinates: means of units enzyme activity/mg. protein (units see Methods). Abscissae : deficiency (0), sufficiency (1) and toxicity (2) levels for $\mathrm{Fe}, \mathrm{Cu}$ and Mo in the culture solution, based on dry weight yield of the felts.

The response of cytochrome $c$ oxidase and cytochrome $c$ reductase to an increase in copper varied markedly. Cytochrome $c$ oxidase was significantly increased from the deficiency to the high levels that depressed yields of the felts by $50 \%$. Cytochrome $c$ reductase, however, was significantly depressed at the highest concentration of the metal.

Effect of molybdenum. The enzymes differed in their response to molybdenum. Although the mean values for catalase or peroxidase activity were not significantly different for the various Mo treatments there was a tendency 
for an increase in activity of these two enzymes from deficiency to the sufficiency level, followed by a depression at concentrations that depressed felt weight.

Cytochrome $c$ reductase was significantly depressed by increasing Mo from deficiency to values that were associated with a depression in the yields of felts. The oxidase showed a similar trend and the difference between the $\mathrm{Mo}_{\mathbf{1}}$ and $\mathrm{Mo}_{2}$ treatments was significant.

In vitro experiments. The only effect of adding $\mathrm{Cu}$ or $\mathrm{Mo}$ in vitro at $1 \mu \mathrm{g}$. to $0.1 \mathrm{ml}$. extract of normal felts was to increase the endogenous rates of peroxidase and cytochrome $c$ oxidase.
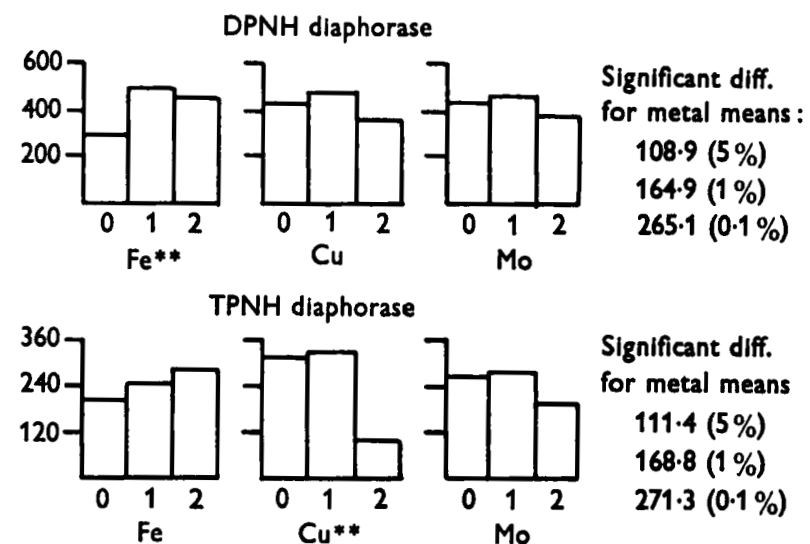

TPNH diaphorase
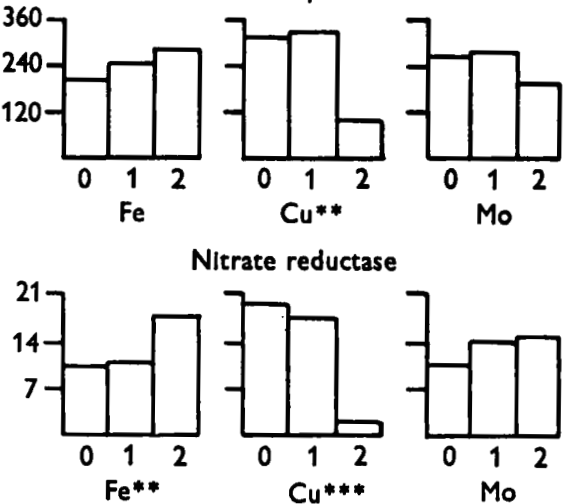

Significant diff.

for metal means

$111.4(5 \%)$

$168.8(1 \%)$

$271.3(0.1 \%)$

Nitrate reductase
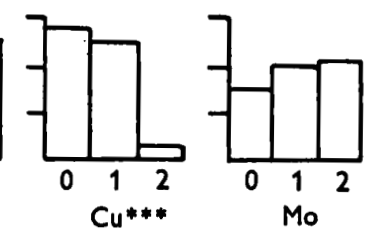

Significant diff.

for metal means :

$4.456(5 \%)$

$6.750(1 \%)$

$10.851(0.1 \%)$

Nitrite reductase
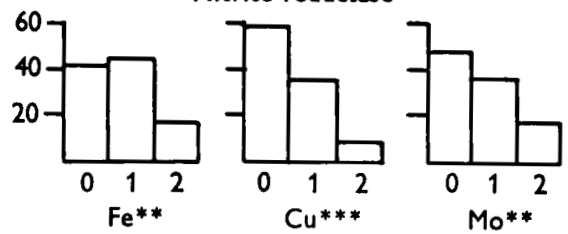

Significant diff.

for metal means

$12.21(5 \%)$

$18.50(1 \%)$

$29.74(0.1 \%)$

$$
\text { Significant at: * }(5 \% \text { level }) ; * *(1 \% \text { level }) ; * * *(0.1 \% \text { level }) \text {. }
$$

Fig. 2. Ordinates: means of units enzyme activity/mg. protein (units see Methods). Abscissae: deficiency (0), sufficiency (1) and toxicity (2) levels for $\mathrm{Fe}, \mathrm{Cu}$ and $\mathrm{Mo}$ in the culture solution, based on dry weight yield of the felts.

\section{Flavoprotein enzymes}

Effect of iron. The contents of DPNH diaphorase, nitrate and nitrite reductases were significantly changed by the iron treatments as shown in Fig. 2. The TPNH diaphorase showed a gradual increase from the deficiency to the 
toxicity level, based on yield of felts. The DPNH diaphorase was significantly increased in activity from the $\mathrm{Fe}_{0}$ to the $\mathrm{Fe}_{1}$ level.

Nitrate and nitrite reductases showed opposite effects in their response to iron at the highest concentration; the former enzyme activity was stimulated whereas that for the nitrite reductase was depressed.

Effect of copper. Increasing copper from sufficiency to toxicity concentrations based on the weight of mycelial felts, depressed both DPNH and TPNH diaphorases, these effects, however, just failed to reach significance for the latter enzyme. Nitrate and nitrite reductases were significantly depressed at the highest concentrations of copper.

Effect of molybdenum. Molybdenum status did not significantly affect the diaphorase enzymes although a high level of the micronutrient tended to depress them. Nitrate reductase increased from $\mathbf{M o}_{0} \rightarrow \mathbf{M o}_{1} \rightarrow \mathbf{M o}_{2}$ whereas nitrite reductase showed the opposite effect.

In vitro studies. The addition of $\mathrm{Cu}$ or Mo at $1 \mu \mathrm{g}$. to $0.1 \mathrm{ml}$. extract of normal felts had no effect either on DPNH or TPNH diaphorases. Nitrate and nitrite reductases were, however, depressed at this $\mathrm{Cu}$ concentration.

\section{Phosphatases}

Alkaline phosphatase was not changed by the treatments given whereas the acid phosphatase was significantly depressed when molybdenum was in excess as shown in Fig. 3.

\section{Alkaline phosphatase}
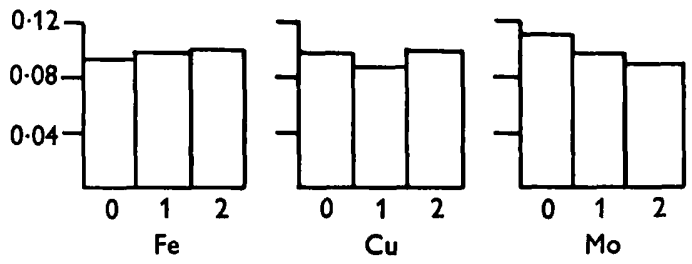

Significant diff.

for metal means:

$0.024(5 \%)$

$0.036(1 \%)$

$0.058(0.1 \%)$

Acid phosphatase
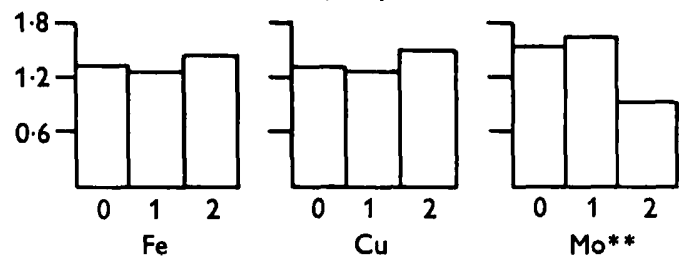

Significant diff.

for metal means :

$0.350(5 \%)$

$0.531(1 \%)$

$0.853(0.1 \%)$

Significant at: * $(5 \%$ level $) ; * *(1 \%$ level $) ; * * *(0.1 \%$ level $)$.

Fig. 3. Ordinates: means of units enzyme activity/mg. protein (units see Methods). Abscissae: deficiency (0), sufficiency (1) and toxicity (2) levels for $\mathrm{Fe}, \mathrm{Cu}$ and $\mathrm{Mo}$ in the culture solution, based on dry weight yield of the felts.

In vitro experiments. Alkaline phosphatase was unchanged by the addition either of $\mathrm{Cu}$ or Mo to the extracts. The results of in vitro experiments with acid phosphatase are shown in Table 1. Molybdate markedly depressed acid phosphatase whereas $\mathrm{Cu}$ stimulated its activity. The addition of $\mathrm{Cu}$ partially 
reversed the inhibition by molybdate whereas $\mathbf{F e}, \mathbf{M n}$ and $\mathrm{Zn}$ were without effect. Vanadate or tungstate also markedly depressed the enzyme.

Table 1. The effect of metal addition in vitro on the activity of acid phosphatase

Values as percentage of normal

Control $\mathrm{FeCl}_{3} \mathrm{MnCl}_{2} \mathrm{ZnSO}_{4} \mathrm{CuSO}_{4}\left(\mathrm{NH}_{4}\right)_{6} \mathrm{Mo}_{7} \mathrm{O}_{24} \cdot 4 \mathrm{H}_{2} \mathrm{O} \mathrm{NH} \mathrm{NO}_{3} \mathrm{Na}_{2} \mathrm{WO}_{4} \cdot 2 \mathrm{H}_{2} \mathrm{O} \mathrm{Cu}+\mathrm{Mo}$

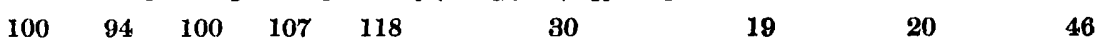

$1 \mu \mathrm{g}$. of each metal added to the reaction mixture which consisted of: $1 \mathrm{ml}$. acid phosphatase reagent and $0.05 \mathrm{ml}$. enzyme extract incubated at $38^{\circ}$ for $30 \mathrm{~min}$. and made to a final volume of $5 \mathrm{ml}$. with $0.06 \mathrm{~N}-\mathrm{NaOH}$.

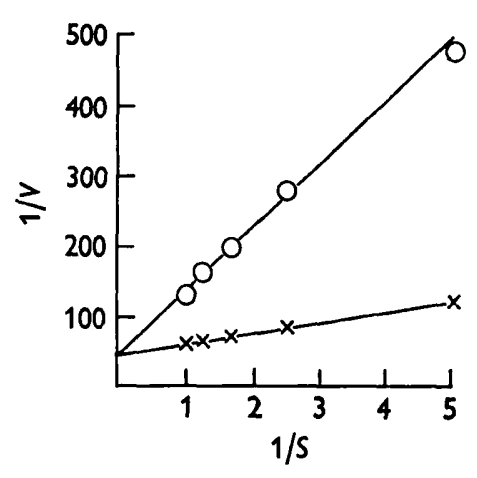

Fig. 4

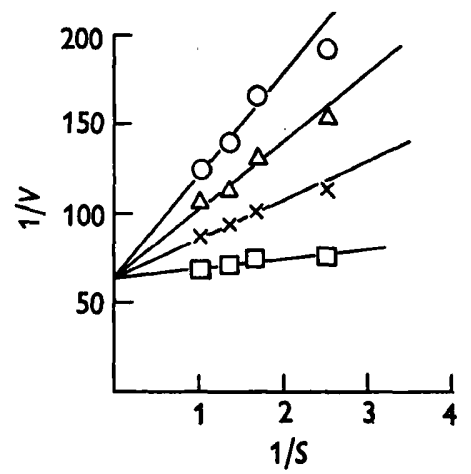

Fig. 5

Fig. 4. Lineweaver-Burk (1934) plot of the competitive inhibition of acid phosphatase activity by sodium molybdate. Assay mixtures consisted of $1 \mathrm{ml}$. acid phosphatase reagent, $0.05 \mathrm{ml}$. enzyme extract and $0.05 \mathrm{ml}$. of either distilled water or a solution of $\mathrm{Na}_{2} \mathrm{MoO}_{4}$ of $8 \mu \mathrm{g}$. $\mathrm{Mo} / \mathrm{ml}$. The mixtures were incubated at $38^{\circ}$ for $30 \mathrm{~min}$. and then $3.9 \mathrm{ml}$. of $0.06 \mathrm{~N}-\mathrm{NaOH}$ were added to make a final volume of $5 \mathrm{ml}$. The intensity of the $p$-nitrophenol colour developed was read on the Spekker Absorptiometer at $540 \mathrm{~m} \mu$. $1 / \mathrm{V}$, reciprocal of the intensity of the $p$-nitrophenol at $540 \mathrm{~m} \mu . \times 10^{4} ; 1 / \mathrm{S}$, reciprocal of substrate concentration where the normal substrate concentration is considered as unity. $x-x$, no inhibitor; $O-0$, with molybdate.

Fig. 5. Lineweaver-Burk (1934) plot showing competitive inhibition of copper by molybdate on acid phosphatase (in vitro). Assay mixtures consisted of $1 \mathrm{ml}$. acid phosphatase reagent, $0.05 \mathrm{ml}$. enzyme extract, $0.05 \mathrm{ml}$. $\mathrm{Na}_{2} \mathrm{MoO}_{4} .2 \mathrm{H}_{2} \mathrm{O}$ at $0,10,2 \cdot 1$ or $5 \cdot 2 \times 10^{-6} \mathrm{M}$ $\mathrm{Na}_{2} \mathrm{MoO}_{4} .2 \mathrm{H}_{2} \mathrm{O}$ and $0.05 \mathrm{ml}$. $\mathrm{CuSO}_{4} .5 \mathrm{H}_{2} \mathrm{O}$ at $0.6,0.9,1.2$ and $1.5 \times 10^{-5} \mathrm{M}$. The mixtures were incubated at $38^{\circ}$ for $30 \mathrm{~min}$. and then $3.85 \mathrm{ml} .0 .06 \mathrm{~N}-\mathrm{NaOH}$ were added to make a final volume of $5 \mathrm{ml}$. The intensity of the $p$-nitrophenol colour developed was read on the Spekker absorptiometer at $540 \mathrm{~m} \mu .1 / \mathrm{V}$, reciprocal of the intensity of the $p$-nitrophenol at $540 \mathrm{~m} \mu . \times 10^{4} ; 1 / \mathrm{S}$, reciprocal of the amount of copper added per assay.

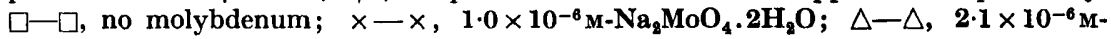
$\mathrm{Na}_{2} \mathrm{MoO}_{4} \cdot 2 \mathrm{H}_{2} \mathrm{O} ; \mathrm{O}-\mathrm{O}, \mathbf{5 \cdot 2} \times 10^{-6} \mathrm{M}^{-\mathrm{Na}_{2}} \mathrm{MoO}_{4} \cdot 2 \mathrm{H}_{2} \mathrm{O}$.

Fig. 4 shows that molybdate inhibits the enzyme competitively. The $\boldsymbol{K}_{m}$ for the enzyme-substrate complex was calculated to be $1 \cdot 6 \times 10^{-3} \mathrm{M}$ and the dissociation constant for the enzyme-inhibitor complex was $0.68 \times 10^{-5} \mathrm{M}$.

The results in Fig. 5 demonstrate the competitive nature of the inhibition of $\mathrm{Cu}$ by molybdate (in vitro) on acid phosphatase. 


\section{DISCUSSION}

Although it is well established that $\mathrm{Mo}$ and $\mathrm{Cu}$ are antagonistic in animal nutrition experiments, little work has been done on enzyme changes which occur in the tissues under these conditions. Changes in enzyme pattern in Neurospora crassa given different amounts of $\mathrm{Cu}$, Mo and $\mathrm{Fe}$, reported in this paper, illustrate that some key enzymes, drastically decreased by one of these metals, may be partially restored by increasing one of the other two in the culture solution. Thus the activity of cytochrome $c$ oxidase was enhanced by adding $\mathrm{Cu}$, whereas amounts of Mo that decreased felt weight, decreased it. A similar result was obtained by van Reen (1953) in the rat where adding $\mathrm{Cu}$ alleviated the effect of $\mathrm{Zn}$ in depressing cytochrome $c$ oxidase in the liver. The effect of $\mathrm{Cu}$ in increasing this enzyme is in keeping with the suggestion that $\mathrm{Cu}$ is a component of the DPNH oxidase system (Green, Basford \& Mackler, 1956).

The opposite effect was obtained with nitrate reductase, a molybdo-flavoprotein, where an increase in Mo enhanced its activity and $\mathrm{Cu}$ depressed it. The addition of $\mathrm{Cu}$ also depressed the enzyme in vitro but the addition of Mo failed to restore the low activity of nitrate reductase prepared from Mo-deficient felts (Nicholas, Nason \& McElroy, 1954).

Cytochrome $c$ reductase was decreased when $\mathrm{Cu}$ was in excess, in contrast to a substantial increase in its oxidase, whereas iron treatments increased both enzymes. The effects of $\mathrm{Cu}$ excess on cytochrome $c$ reductase is unlikely to be caused by interference with haem-iron because the oxidase activity is enhanced under similar conditions. $\mathrm{Cu}$ excess may, therefore, affect the nonhaem-iron which is only present in the reductase system.

A number of enzymes decreased by toxic concentrations of one of the metals were either not increased by varying the concentrations of the other two in the culture solution or were depressed further. Thus, it appears that nutrient antagonisms are reflected by some enzymes only and in this study these were metallo-proteins.

Acid phosphatase was depressed by increasing Mo from sufficiency to toxicity levels (based on dry weight of the felts), thus confirming a similar effect observed in higher plants (Spencer, 1954). Molybdate is shown to be a competitive inhibitor of copper in acid phosphatase in vitro. Vanadate and tungstate had a similar inhibitory effect to molybdate, presumably because they too form complexes in acid solution with $p$-nitrophenyl phosphate, the substrate for the phosphatase. It is noteworthy that alkaline phosphatase was unaffected because the substrate-molybdate complex is unstable at $\mathrm{pH} \mathrm{10 \cdot 3}$; the $\mathrm{pH}$ at which the assay is made.

In these experiments, substantial differences were required between mean values before significant effects were obtained. This was in the main due to the limited number of replicates that could be conveniently handled in enzyme work of this nature. For this reason some effects known to occur in previous experiments just failed to reach significance in these studies, e.g. a greater catalase and peroxidase activity in felts given optimal Mo (Nicholas, 1956). 
Thanks are due to Mr G. M. Clarke for advice in regard to the design and the statistical analysis of the experiments. One of us (K. C). is grateful to the Leverhulme Foundation for a colonial scholarship which made participation in this work possible.

\section{REFERENCES}

Bessey, O. A., Lowry, O. H. \& Brock, M. J. (1946). A method for the rapid determination of alkaline phosphatase with five cubic millimetres of serum. J. biol. Chem. 164, 321.

Commissiong, K. \& Nicholas, D. J. D. (1957). Effects of molybdenum and copper on some enzymes in Neurospora. Nature, Lond. 180, 555.

Feinstein, R. N. (1949). Perborate as substrate in a new assay of catalase. J. biol. Chem. 180, 1197.

Green, D. E., Basford, R. E. \& Mackler, B. (1956). The role of iron and copper in terminal electron transfer in Inorganic Nitrogen Metabolism, Ed. McElroy, W. D. \& Glass, B. p. 628. Baltimore: The Johns Hopkins Press.

Healy, W. B., Cheng, S. \& McElroy, W. D. (1955). Metal toxicity and iron deficiency effects on enzymes in Neurospora. Arch. Biochem. Biophys. 54, 206.

Lineweaver, H. \& Burk, D. (1934). The determination of enzyme dissociation constants. J. Amer. chem. Soc. 56, 658.

Lowry, O. H., Rosebrough, N. J., Fark, A. L. \& Randall, R. J. (1951). Protein measurement with the folin phenol reagent. J. biol. Chem. 193, 265.

Medina, A. \& Nicholas, D. J. D. (1957). Interference by reduced pyridine nucleotides in the diazotization of nitrite. Biochim. biophys. Acta, 23, 440.

Nicholas, D. J. D. (1952). The use of fungi for determining trace metals in biological materials. Analyst, 77, 629.

Nicholas, D. J. D. (1956). Effect of molybdenum deficiency on catalase and peroxidase in Neurospora. Nature, Lond. 178, 148.

Nicholas, D. J. D., NAson, A. \& McElroy, W. D. (1954). Molybdenum and nitrate reductase. 1. Effect of molybdenum deficiency on the Neurospora enzyme. J. biol. Chem. 207, 341.

Pullman, M. E., Colowick, S. P. \& Kaplan, N. O. (1952). Comparison of diphosphopyridine nucleotide with its deaminated derivative in various enzyme systems. J. biol. Chem. 194, 593.

ReEN, R. van (1953). Effects of excessive dietary zinc in the rat and the interrelationship with copper. Arch. Biochem. Biophys. 46, 337.

Smith, F. G., Robinson, W. B. \& Stotz, E. (1949). A colorimetric method for the determination of peroxidase in plant material. J. biol. Chem. 179, 881.

Sмiтн, F. G. \& Stotz, E. (1949). A colorimetric method for the determination of cytochrome oxidase. J. biol. Chem. 179, 891.

Spencer, D. (1954). The effect of molybdate on the activity of tomato acid phosphatases. Aust. J. biol. Sci. 7, 151.

(Received 17 June 1957) 